\title{
Electrochemical Technology for Wastewater Treatment: Dares and Trends
}

\author{
Djamel Ghernaout ${ }^{1,2^{*}}$, Noureddine Elboughdiri ${ }^{1,3}$ \\ ${ }^{1}$ Chemical Engineering Department, College of Engineering, University of Ha'il, Ha'il, Saudi Arabia \\ ${ }^{2}$ Chemical Engineering Department, Faculty of Engineering, University of Blida, Blida, Algeria \\ ${ }^{3}$ Département de Génie Chimique de Procédés, Laboratoire Modélisation, Analyse, et Commande des systèmes, Ecole Nationale \\ d'Ingénieurs de Gabès (ENIG), Gabès, Tunisia \\ Email: ${ }^{\star d j a m e l \_a n d a l u s @ h o t m a i l . c o m ~}$
}

How to cite this paper: Ghernaout, D. and Elboughdiri, N. (2020) Electrochemical Technology for Wastewater Treatment: Dares and Trends. Open Access Library Journal, 7: e6020.

https://doi.org/10.4236/oalib.1106020

Received: December 23, 2019

Accepted: January 3, 2020

Published: January 6, 2020

Copyright () 2020 by author(s) and Open Access Library Inc.

This work is licensed under the Creative Commons Attribution International License (CC BY 4.0).

http://creativecommons.org/licenses/by/4.0/

(c) (i) Open Access

\begin{abstract}
For treating wastewater, electrochemical engineering has been rediscovered during the last four decades through the world for its inherent advantages comparatively with traditional technologies especially the chemical and biological techniques. However, the expansion of this technology founded on electric current applying has been retarded by several technical-economic factors especially the detection of disinfection by-products (DBPs) formation. This work focuses on the challenges and future tendencies for this highly-efficient technology to reach the full-scale implementations particularly in disinfecting water. Lately, new versions of electrochemical techniques have been suggested such as employing sulfate radical anion $\left(\mathrm{SO}_{4}^{--}\right)$and sunlight to generate ${ }^{\bullet} \mathrm{OH}$ radicals in $\mathrm{TiO}_{2}$ photocatalysis and photo-Fenton water treatment. These improvements elevated the electrochemical engineering efficiency and acceptation. However, more efforts remain to be accomplished for water reuse vision. Future researches would focus on integrating membranes processes such as nanofiltration and reverse osmosis for a safe removal of DBPs.
\end{abstract}

\section{Subject Areas \\ Environmental Sciences}

\section{Keywords}

Wastewater Treatment, Electrochemical Engineering, Electrodisinfection, Electrocoagulation, Electroflotation, Electrooxidation

\section{Introduction}

Implementing the electrochemical technique in ecological treatment has been 
the subject of numerous investigations during the last four decades [1]. Thousands of researches have focused on presenting novel techniques or enhancing previous methods (Figure 1). Following these extended years, very few techniques are being used at full-scale and most processes assessed are only viewed as "encouraging" methods. Most possess established advantages; however, considerable practical and cost hindrances may be listed, which remain linked to lost pieces in the gain series of the technique [2].

Electrolytic techniques involve the cathodic deposition of metals observed in the largely employed electrowinning and electrorefining methods and the oxidation of organic matters [3] [4] [5] [6], either directly on the anode surface or mediated via oxidants formed on the anode or on the cathode surface [7] [8]. This last situation is of huge importance since hydrogen peroxide $\left(\mathrm{H}_{2} \mathrm{O}_{2}\right)$ may be efficaciously generated from the reduction of oxygen employing gas diffusion electrodes (GDEs) [2] [9] or more newly utilizing cross-flow electrodes surprisingly with implementing elevated pressures [2], conducting to more performant techniques. Moreover, electrocoagulation (EC) processes are launched through liberating electrolytically coagulants from a sacrificial anode and may be utilized to fragment emulsions in industrial wastes or to eliminate colloid contaminants in such wastes and in the course of treating surface water [10] [11] [12] [13] [14].

Not only electrodialysis [15] and capacitive deionization [16] (which let the concentration of ions in liquids) are comprised in electrochemically assisted separation

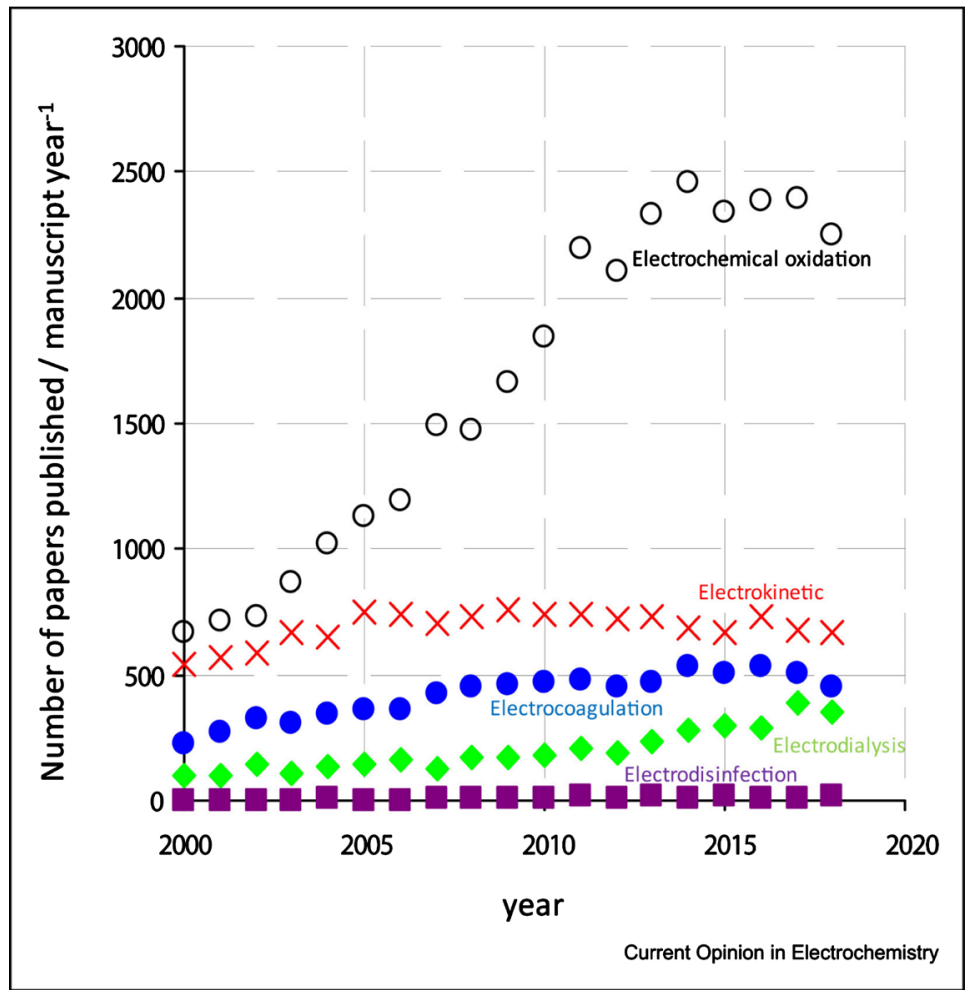

Figure 1. Number of publications per year related to different environmental electrochemical technologies according to Scopus [2]. 
methods, but as well electrokinetic techniques (which permit the transfer of species in solid-liquid mixtures like soil or sludge) [2] [17] [18].

Not all electrochemically founded techniques are at the identical technology readiness level (TRL) (Figure 2) [2]. Huge gaps are observed among electrowinning or electrodialysis and the electrolysis of wastewater contaminated with organic chemicals. Occasionally, comprehending such gaps is required for companies wanting to expand these techniques, particularly if there is a shortage of choices. If competitive alternatives are completely merchandised, it is hard to dislodge them, except if the benefits of the fresh technique would assist to reach a so quick return. Morals have to be taught concerning the prosperous application of electrodialysis and electrodeposition of metals, to attain total pertinency of different electrochemical techniques and to permit paybacks on spent money to companies and society. Plenty of electrochemical techniques, comprising the electrochemical oxidation of wastewater, electrodisinfection [19] [20] [21] [22] [23] and soil electroremediation are presently in status to elevate TRLs [24]. Occasionally, the dare to be confronted is practical; in other circumstances it is economic.

The following concentrates on a short description of electrodisinfection [25]. Further, this work discusses the needed procedures to attain the full-scale utilizations of the green electrochemical engineering especially in disinfecting wastewater.

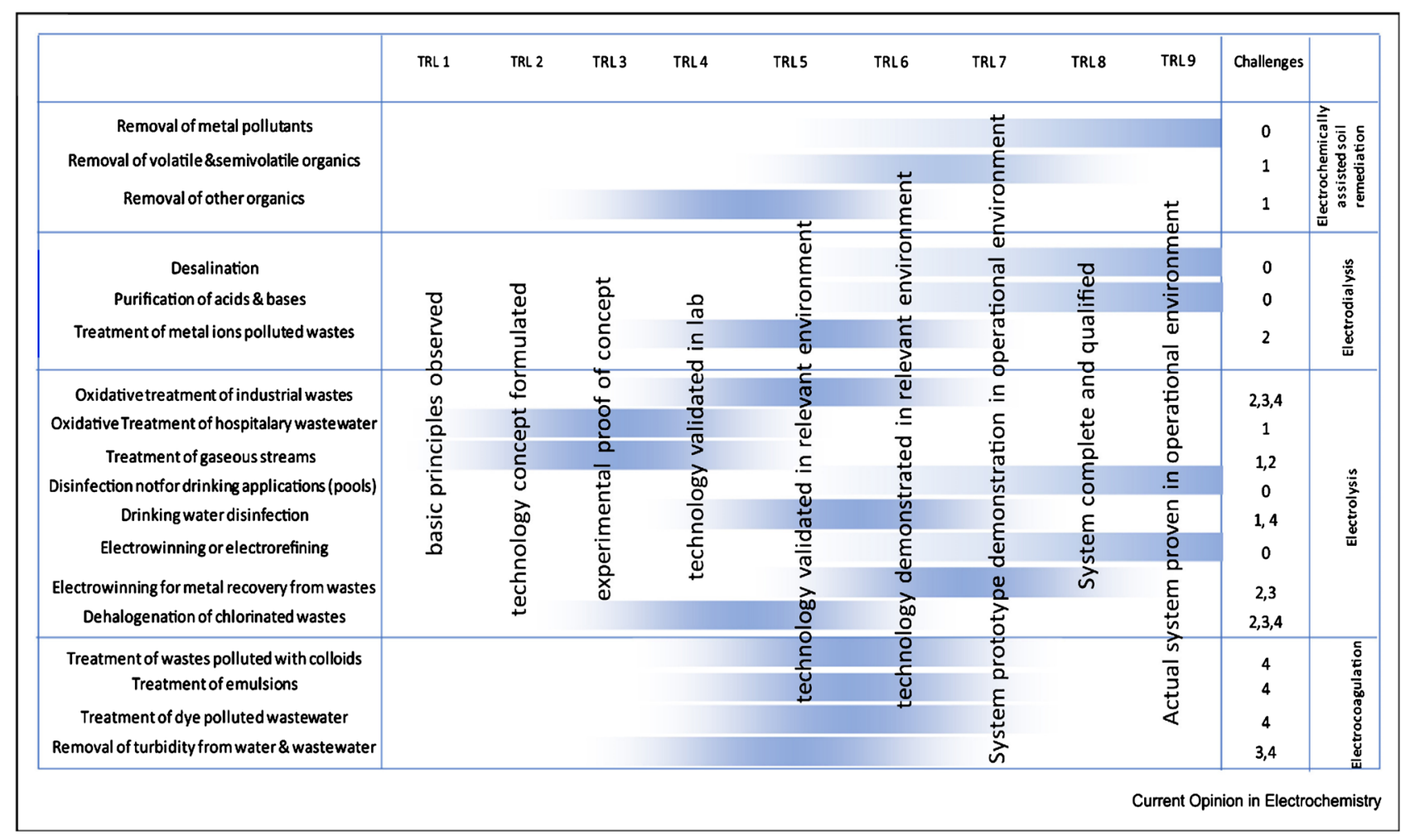

Figure 2. TRL of the main environmental electrochemical technologies, including the key challenges that have to be overpassed to increase this level: no significant challenges (0); further fundamental work (1); components development (membranes, electrodes, cells, etc.) (2); scale up (3); competition with efficient technologies (4). TRL: technology readiness level [2]. 


\section{Environmental Electrochemical Technology: One-Step Closer to Let Full-Scale Usages}

\subsection{Dares in Electrochemically Disinfecting Water}

During the time that the employment of mixed metal oxide anodes has been revealed for disinfecting water, especially generating chlorinated disinfectants, a hard work stays to drive the technique from classical disinfection of saline swimming pools or spas, in which numerous small and medium enterprises (SMEs) are concentrating their business [2] [26].

With a view to satisfying this perspective, two key dares should be resolved. The first one is to define how to evade the generation of toxic by-products like chlorates or trihalomethanes [13] [27]. Chlorates are produced via oxidation of hypochlorite or by its disproportionation, which is a natural phenomenon that also takes place through the aging of the disinfected water [28]. This chemical is linked to grave health issues as it is established to touch the nervous system. The second kind of dangerous agents is surprisingly more debatable. Chlorinated chemicals are produced from the integration of organic matter with active species of chlorine; however, such agents are linked to cancer and other so severe illnesses. These chemicals are not distinctive of the electrochemical technology since they are also created through the usage of traditional chlorination techniques [28] [29] [30] [31]. The additional dare remains in implementing changes for mixed metal oxide anodes, like diamond-like coatings, which are able both to oxidize chloride ions and generate more performant disinfectants, comprising hydroxyl radicals $\left({ }^{\bullet} \mathrm{OH}\right)$ [32] [33] [34]. If utilizing such electrodes, issues related to the formation of dangerous chemicals may be worsened, since the well-known generation of perchlorates throughout oxidation of chlorates [2]. Such fresh electrode materials conquer the hope of encouraging the contribution of diverse oxidizing species, like, ozone and peroxosalts [35] to assist eliminate resistant pathogens. Appropriate residence period among water and the anodes in the electrolyzer, an enough big specific current, and the cathodic production of $\mathrm{H}_{2} \mathrm{O}_{2}$ to avoid more oxidation of chlorine to chlorates and perchlorates remain between precautions viewed to bypass such issues [36].

Chen et al. [37] followed the conversion of roxarsone (ROX) throughout UV disinfection employing $\mathrm{Fe}(\mathrm{III}) . \mathrm{Fe}(\mathrm{OH})^{2+}$, as the main $\mathrm{Fe}(\mathrm{III})$ species at $\mathrm{pH}=3$, forms ${ }^{\bullet} \mathrm{OH}$ under UV irradiation conducting to the oxidation of ROX. Dissolved oxygen [38] has an extremely significant contribution in the constant transformation of produced $\mathrm{Fe}^{2+}$ to $\mathrm{Fe}^{3+}$, which guarantees a $\mathrm{Fe}(\mathrm{III})-\mathrm{Fe}(\mathrm{II})$ cycle in the device. The existence of $\mathrm{Cl}^{-} / \mathrm{HCO}_{3}^{-} / \mathrm{NO}_{3}^{-}$has a small impact on the ROX conversion; however, $\mathrm{PO}_{4}^{3-}$ attains an evident inhibitory influence. The conversion of ROX conducts to the generation of inorganic arsenic comprising a much higher quantity of $\mathrm{As}(\mathrm{V})$ than As(III). LC-MS analysis depicts that phenol, $o$-nitrophenol, and arsenic acid were the major conversion products. Both the radical scavenger test and electron spin resonance data establish that the ${ }^{\bullet} \mathrm{OH}$ is in charge of ROX 
conversion. The poisonous transformation products are observed to possess inherent ecological dangers for nature, organisms, and humans.

\subsection{Dares Allowing Electrocoagulation (EC) to Rival with Coagulation}

Electrocoagulation (EC) remains another possibility of chemical coagulation [39]. In EC, the coagulant is furnished via solubilizing sacrificial electrodes [40]. The ease of running and the secondary phenomena implying the formation of bubbles are the main benefits. In the first situation, the injection of coagulant may be set easily by adjusting the current intensity applied, and the manipulation of chemicals is averted. In the second circumstance, a suitable mechanical cell scheme may assist to use oxygen and hydrogen microbubbles to enhance turbulence and improve the flocculation of particles (in so-named electroflocculation). Every so often, separation may be elevated through flotation, once microbubbles have fixed to the surface of the flocs, reducing their global density (in so-named electroflotation [14] [41]). In chemical coagulation, the chemicals are usually salts of iron [42] or aluminum [30]; the principal-agent in EC remains hydroxyl ions with $\mathrm{Fe}^{2(3)+} / \mathrm{Al}^{3+}$ [43] [44] [45], and the counterion does not elevate the salinity of the treated water. In traditional coagulation, salts injected work as Lewis acids and necessitate neutralization [46] through alkali additions, to reach an appropriate $\mathrm{pH}$. This elevates both the salt charge of the treated waste and the volume of sludge, conducting to an effluent with so more important conductivity [2]. Reciprocally, $\mathrm{EC}$ by itself adjusts the $\mathrm{pH}$, so there is no need of introducing $\mathrm{pH}$-neutralizing chemicals [47] [48] [49] [51].

Even if conceiving an EC at the lab-scale remains so easy, its scale-up stays difficult [40] [52] [53] [54]. On the other hand, it is not forever doable to employ tank cells with sheets of iron and aluminum; further, there is a requirement to utilize cheap materials as sacrificial electrodes [2] [55]. Employing low-quality iron or aluminum could let bipolar electrode arrangements to be utilized [56] [57] [58]. Integrating EC with free radical-assisted techniques stays an encouraging procedure to promote its application at full scale [59] [60] [61] [62] [63].

\subsection{Dares in Dealing with Industrial Wastes}

During the last decade, one of the most thrilling research fields has been the expansion of techniques dealing with industrial wastes in situations where using biological processes and else inexpensive methods are inactive [2] [64] [65] [66] [67]. In this context, numerous methods have been suggested, most of them being categorized as advanced oxidation processes (AOPs) [32] [33] [34]. The fundamental oxidant implicated is the ${ }^{\bullet} \mathrm{OH}$. This radical possesses two magnificent benefits as contrasted with diverse conventional oxidants, as in the instance of chlorine: the ${ }^{\bullet} \mathrm{OH}$ diminishes the production of dangerous by-products [68] and could be quicker and more efficacious, due to the severe oxidation circumstances. For all the excellent expansions in this domain, illustrated in a huge amount of publications, numerous dares stay [69]. 
With respect to the link among such AOPs and electrochemical engineering, many characteristics should be mentioned: 1) the affirmation in 2003 of the strong contribution of hydroxyl radicals in the electrochemical oxidation with diamond electrodes [70]; and 2) the application of the integration of Fenton and electrochemical techniques [71] [72] conducted to the admission of a fresh class of AOP methods, i.e., electrochemical AOPs [2] [73] [74] [75].

Concerning the existing situation of this technique, implementing electrochemical AOPs for eliminating numerous kinds of organic contaminants has been largely investigated [2]. Numerous researches have been dedicated to clarifying the contribution of electrochemical cell schemes and sorts of electrode on the electrochemical phenomena. It has been emphasized that a fundamental need in the inherent pertinence of electrochemical engineering resides in the judicious usage of all the pieces of the electrochemical setup [76] [77] [78]. This involves not only the usage of an appropriate anode but also the synergistic usage of the cathode reaction and the advancement of mediated oxidation methods in the bulk throughout the remediation. Moreover, enhancing the mass transfer rate within the device is also crucial. Consequently, the efficacious mechanical conception of the setup and a judicious selection of the running parameters are fundamental to attain excellent efficiency. For all such attempts, the technique stays at an average TRL (Figure 2) and huge expansions are required to attain bigger readiness degrees which admit the appropriate mechanical scheme of the electrochemical device to reach excellent models for flow and current distribution [79], scale-up either via elevating electrode size of through stacking [80], the control of hydrogen formed [81] [82] and direct current electrical power necessities [83].

\subsection{Dares in Sanitary Effluents: Perspective for Electrochemical Technology}

Hospitals generate sanitary effluents with an elevated charge of a huge diversity of chemical products (like pharmaceuticals, detergents, disinfectants, heavy metals, radionuclides) and highly pathogenic microorganisms [2]. Usually, they are immediately ejected in public sewage for remediation at traditional urban wastewater treatment plants (WWTPs). The inadequacy of biological processes at the WWTPs to deal with sanitary effluents conducts to the dispersal of hazardous chemicals and pathogens in nature, destructively influencing both aquatic organisms and human health [84]. Consequently, many investigations focused on technical solutions to diminish the effect of sanitary effluents in nature [85]. Two major programs have been proposed: 1) supporting efficient treatments at WWTPs via implementing supplementary remediation; and 2) pretreatment prior to introducing them into WWTPs [2]. The last choice is rising as the fundamental substitute since it deals with the issue in more concentrated effluents and the volume of wastewater handled is further much lower than in the first situation. Included in the accessible techniques, a solo electrochemical approach like electrochemical oxidation or electro-Fenton and the integration of free radical-assisted electrochemical technologies have shown total disinfection and partial oxidation of 
chemicals towards the reduction of toxicity and augmentation of biodegradability of sanitary effluents [2].

Olvera-Vargas et al. [86] proposed a sequential electrochemical process for integral treatment of anaerobic sludge, merging for the first time electrochemical peroxidation (ECP) and electro-Fenton (EF). In the first stage, ECP (consisting of $\mathrm{H}_{2} \mathrm{O}_{2}$-assisted EC with Fe electrodes [87]) was used as a conditioning and stabilizing technique, whose synergistic EC/Fenton oxidation impacts greatly diminished the COD, TOC and total suspended solids (TSS) by $89.3 \%, 75.4 \%$ and $85.6 \%$, respectively, under regulated parameters (initial pH of $5,\left[\mathrm{H}_{2} \mathrm{O}_{2}\right] /\left[\mathrm{Fe}^{2+}\right]$ dose ratio of $5,15.38 \mathrm{~mA} / \mathrm{cm}^{2}$ and $2 \mathrm{~h}$ treatment). In addition, total coliforms were completely killed during the first hour of treatment. In the second stage, EF was successfully utilized to mineralize the remaining organic fraction in the liquid effluent after dewatering, attaining $91.6 \%$ and $87.2 \%$ of COD and TOC removal, respectively, after $4 \mathrm{~h}$ of treatment under regulated circumstances ( $\mathrm{pH} 3$ and 25 $\mathrm{mA} / \mathrm{cm}^{2}$ ), while almost total COD and TOC removal was attained in $8 \mathrm{~h}$ (Figure 3). The Fe sludge produced at the end of the ECP treatment was readily dewatered by filtration and $20.9 \mathrm{~g}$ of nutrient-rich dry sludge were formed. The overall cost of the ECP-EF treatment was $\$ \$ 0.05 / \mathrm{L}$ sludge. The merged impacts of coagulation [88]-[96] and Fenton oxidation throughout ECP established that the treatment performance is strongly dependent on the rheological properties of the sludge sample (Figure 4).

\section{Electrochemical Engineering for Disinfecting Water}

\subsection{Demobilizing Pathogens Using Sulfate Radical}

During the last decade, demobilizing pathogens employing sulfate radical anion $\left(\mathrm{SO}_{4}^{--}\right.$) has obtained more and more interest because of increasing requirements

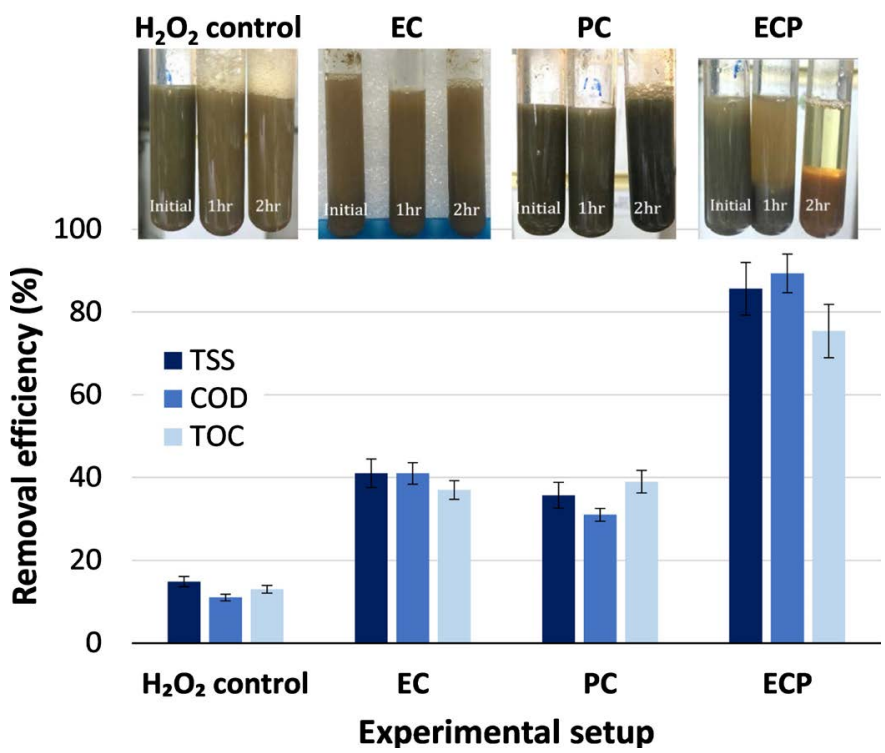

Figure 3. Elimination performance of preliminary tests. Experimental parameters: $V=400$ $\mathrm{mL}, \mathrm{pH}=5, \mathrm{Na}_{2} \mathrm{SO}_{4}=0.1 \mathrm{M}, j=15.38 \mathrm{~mA} / \mathrm{cm}^{2}$, total $\left[\mathrm{H}_{2} \mathrm{O}_{2}\right]=0.24 \mathrm{M}$ (for the control and ECP trials) and 2 h-treatment. The photographs show the sample evolution over time [86]. 


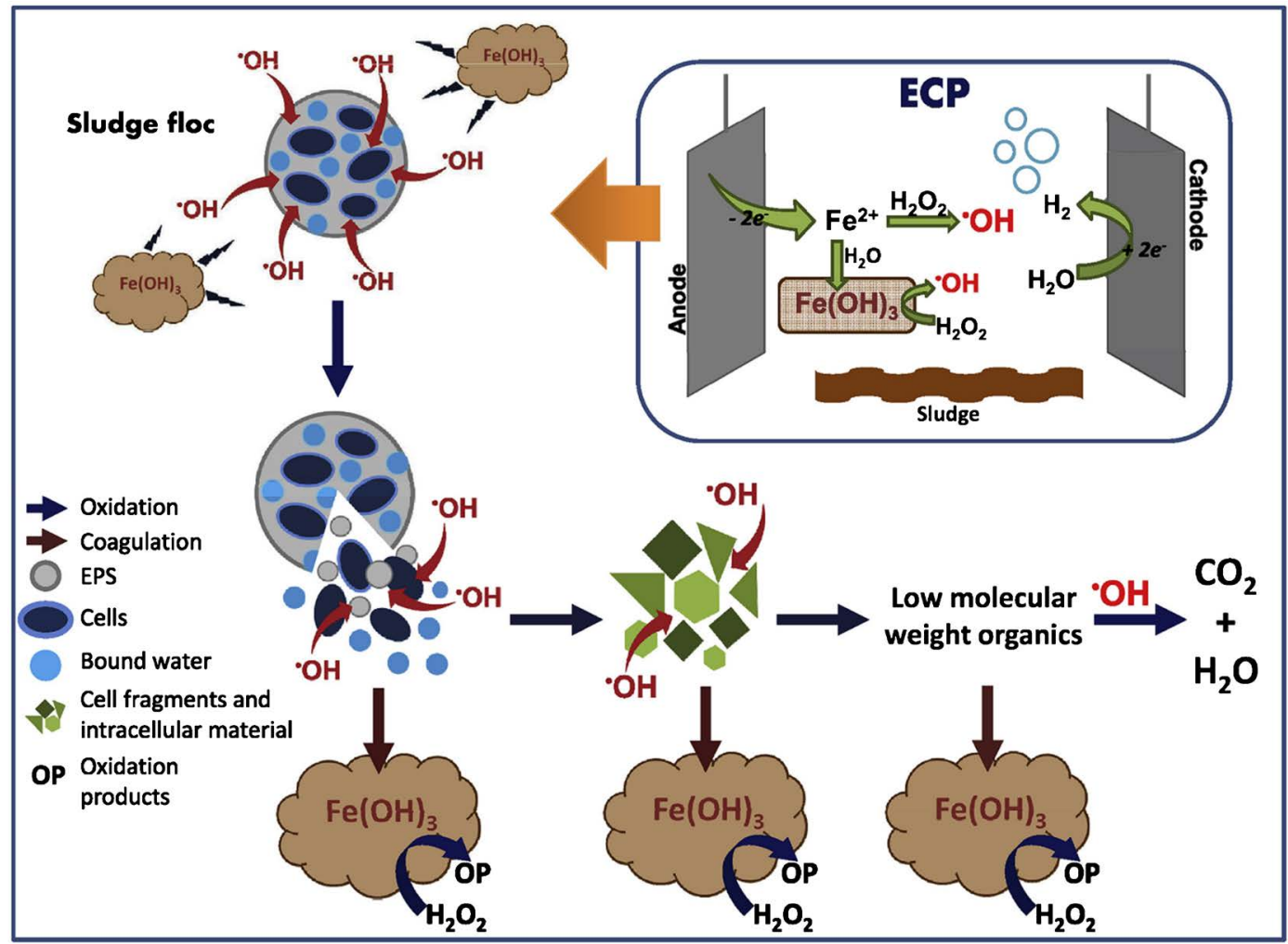

Figure 4. Decomposition pathways occurring throughout ECP of anaerobic sludge. Inset panel: formation of coagulants and oxidants during ECP using mild steel electrodes [86].

to manage toxic disinfection by-products (DBPs) and improve water treatment setups especially for efficacious microbial handling [32] [97]-[102]. Xiao et al. [103] concentrated on the fundamental rules and actual research conditions of $\mathrm{SO}_{4}^{--}$-founded demobilization technique, and juxtaposed it with ${ }^{\bullet} \mathrm{OH}$-founded demobilization of microbes. They discussed the key pathways of radical reactions with biomolecules and the demobilization kinetics and routes via $\mathrm{SO}_{4}^{\cdot-}$. They established that $\mathrm{SO}_{4}^{--}$oxidatively destroys the cell membrane, proteins, and genetic materials (i.e., DNA and RNA), conducting to the demobilization of the microorganisms (Figure 5). They reviewed the present issues, dares, and likely solutions in engineering implementations.

\subsection{Demobilizing Pathogens Using Solar Photocatalytic Processes}

Malato et al. [104] discussed the usage of sunlight to generate ${ }^{\circ} \mathrm{OH}$ radicals in $\mathrm{TiO}_{2}$ photocatalysis and photo-Fenton water treatment. They defined the reaction setups required for solar photocatalysis and presented a global view of utilized compound parabolic collector photoreactors. They explained how solar photocatalysis might greatly participate in dealing with water containing persistent toxic compounds. They presented the usage of solar photocatalysis in demobilizing microbes existing in the water. In the same direction, Alvarez-Guerra et al. [105] sized the Photovoltaic Solar Electro-Oxidation process that merges the effectiveness of the electrochemical oxidation founded on boron-doped anodes 


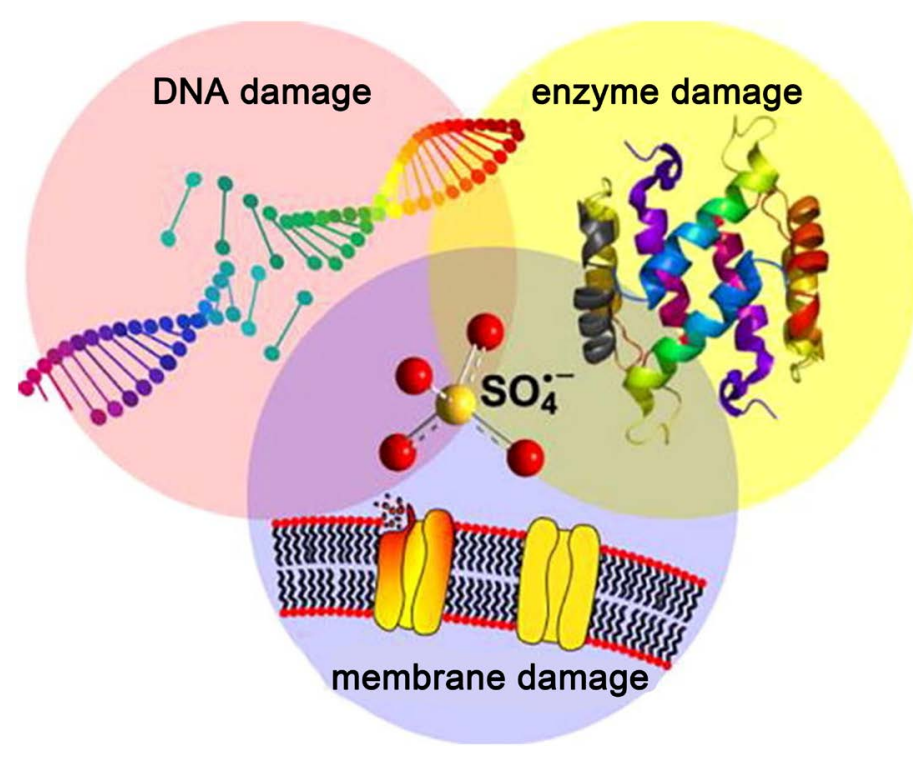

Figure 5. $\mathrm{SO}_{4}^{--}$oxidative destruction of the cell membrane, proteins, and genetic materials [103].

to mineralize organic matter, with the autonomy and environmentally friendly features of photovoltaic solar energy [106].

\subsection{Electrochemical Engineering for Water Reuse}

For water reuse [107] [108] [109] [110] [111], Lefebvre [112] presented the NEWater successful case of water reuse in Singapore and demonstrated that electrochemical approaches will constitute the centerpiece of such infallible projects. Other researchers attained the same conclusion [113] [114] [115] thanks to the established efficiency of the techniques founded on the electric current application.

\section{Conclusion}

For treating wastewater, electrochemical engineering has been rediscovered during the last four decades through the world for its inherent advantages comparatively with traditional technologies especially the chemical and biological techniques. However, the expansion of this technology founded on electric current applying has been retarded by several technico-economic factors especially the detection of DBPs formation. This work focuses on the challenges and future tendencies for this highly-efficient technology to reach the full-scale implementations particularly in disinfecting water. Lately, new versions of electrochemical techniques have been suggested such as employing sulfate radical anion $\left(\mathrm{SO}_{4}^{--}\right)$and sunlight to generate ${ }^{\bullet} \mathrm{OH}$ radicals in $\mathrm{TiO}_{2}$ photocatalysis and photo-Fenton water treatment. These improvements ameliorated the electrochemical engineering. However, more efforts remain to be accomplished for water reuse vision. Future researches would focus on integrating membranes processes [116] [117] [118] [119] [120] such as nanofiltration and reverse osmosis for a safe removal of DBPs. 


\section{Conflicts of Interest}

The authors declare no conflicts of interest regarding the publication of this paper.

\section{References}

[1] Al Aukidy, M., Verlicchi, P. and Voulvoulis, N. (2014) A Framework for the Assessment of the Environmental Risk Posed by Pharmaceuticals Originating from Hospital Effluents. Science of the Total Environment, 493, 54-64. https://doi.org/10.1016/j.scitotenv.2014.05.128

[2] Lacasa, E., Cotillas, S., Saez, C., Lobato, J., Cañizares, P. and Rodrigo, M.A. (2019) Environmental Applications of Electrochemical Technology. What Is Needed to Enable Full-Scale Applications? Current Opinion in Electrochemistry, 16, 149-156. https://doi.org/10.1016/j.coelec.2019.07.002

[3] Ghernaout, D., Ghernaout, B., Saiba, A., Boucherit, A. and Kellil, A. (2009) Removal of Humic Acids by Continuous Electromagnetic Treatment Followed by Electrocoagulation in Batch Using Aluminium Electrodes. Desalination, 239, 295-308. https://doi.org/10.1016/j.desal.2008.04.001

[4] Ghernaout, D., Ghernaout, B. and Kellil, A. (2009) Natural Organic Matter Removal and Enhanced Coagulation as a Link between Coagulation and Electrocoagulation. Desalination and Water Treatment, 2, 203-222.

https://doi.org/10.5004/dwt.2009.116

[5] Ghernaout, D., Ghernaout, B., Boucherit, A., Naceur, M.W., Khelifa, A. and Kellil, A. (2009) Study on Mechanism of Electrocoagulation with Iron Electrodes in Idealised Conditions and Electrocoagulation of Humic Acids Solution in Batch Using Aluminium Electrodes. Desalination and Water Treatment, 8, 91-99.

https://doi.org/10.5004/dwt.2009.668

[6] Saiba, A., Kourdali, S., Ghernaout, B. and Ghernaout, D. (2010) In Desalination, from 1987 to 2009, the Birth of a New Seawater Pretreatment Process: Electrocoagulation-An Overview. Desalination and Water Treatment, 16, 201-217. https://doi.org/10.5004/dwt.2010.1094

[7] Belhout, D., Ghernaout, D., Djezzar-Douakh, S. and Kellil, A. (2010) Electrocoagulation of a Raw Water of Ghrib Dam (Algeria) in Batch Using Iron Electrodes. Desalination and Water Treatment, 16, 1-9. https://doi.org/10.5004/dwt.2010.1081

[8] Ghernaout, D., Mariche, A., Ghernaout, B. and Kellil, A. (2010) Electromagnetic Treatment-bi-Electrocoagulation of Humic Acid in Continuous Mode Using Response Surface Method for Its Optimization and Application on Two Surface Waters. Desalination and Water Treatment, 22, 311-329. https://doi.org/10.5004/dwt.2010.1120

[9] Zhou, W., Meng, X., Gao, J. and Alshawabkeh, A.N. (2019) Hydrogen Peroxide Generation from $\mathrm{O}_{2}$ Electroreduction for Environmental Remediation: A State-of-the-Art Review. Chemosphere, 225, 588-607. https://doi.org/10.1016/j.chemosphere.2019.03.042

[10] Barba, S., Villaseñor, J., Cañizares, P. and Rodrigo, M.A. (2019) Strategies for the Electrobioremediation of Oxyfluorfen Polluted Soils. Electrochimica Acta, 297, 137-144. https://doi.org/10.1016/j.electacta.2018.11.195

[11] Ghernaout, D., Ghernaout, B. and Boucherit, A. (2008) Effect of pH on Electrocoagulation of Bentonite Suspensions in Batch Using Iron Electrodes. Journal of Dispersion Science and Technology, 29, 1272-1275. https://doi.org/10.1080/01932690701857483 
[12] Ghernaout, D. and Naceur, M.W. (2011) Ferrate (VI): In Situ Generation and Water Treatment-A Review. Desalination and Water Treatment, 30, 319-332. https://doi.org/10.5004/dwt.2011.2217

[13] Ghernaout, D., Ghernaout, B. and Naceur, M.W. (2011) Embodying the Chemical Water Treatment in the Green Chemistry-A Review. Desalination, 271, 1-10. https://doi.org/10.1016/j.desal.2011.01.032

[14] Ghernaout, D., Naceur, M.W. and Ghernaout, B. (2011) A Review of Electrocoagulation as a Promising Coagulation Process for Improved Organic and Inorganic Matters Removal by Electrophoresis and Electroflotation. Desalination and Water Treatment, 28, 287-320. https://doi.org/10.5004/dwt.2011.1493

[15] Barrera-Díaz, C., Cañizares, P., Fernández, F.J., Natividad, R. and Rodrigo, M.A. (2014) Electrochemical Advanced Oxidation Processes: An Overview of the Current Applications to Actual Industrial Effluents. Journal of the Mexican Chemical Society, 58, 256-275. https://doi.org/10.29356/jmcs.v58i3.133

[16] Bebelis, S., Bouzek, K., Cornell, A., Ferreira, M.G.S., Kelsall, G.H., Lapicque, F., de Leon, C.P., Rodrigo, M.A. and Walsh, F.C. (2013) Highlights during the Development of Electrochemical Engineering. Chemical Engineering Research and Design, 91, 1998-2020. https://doi.org/10.1016/j.cherd.2013.08.029

[17] Brillas, E. and Martínez-Huitle, C.A. (2015) Decontamination of Wastewaters Containing Synthetic Organic Dyes by Electrochemical Methods. An Updated Review. Applied Catalysis B: Environmental, 166-167, 603-643. https://doi.org/10.1016/j.apcatb.2014.11.016

[18] Cameselle, C. and Gouveia, S. (2018) Electrokinetic Remediation for the Removal of Organic Contaminants in Soils. Current Opinion in Electrochemistry, 11, 41-47. https://doi.org/10.1016/j.coelec.2018.07.005

[19] Ghernaout, D., Badis, A., Ghernaout, B. and Kellil, A. (2008) Application of Electrocoagulation in Escherichia coli Culture and Two Surface Waters. Desalination, 219, 118-125. https://doi.org/10.1016/j.desal.2007.05.010

[20] Ghernaout, D. and Elboughdiri, N. (2019) Water Disinfection: Ferrate (VI) as the Greenest Chemical-A Review. Applied Engineering, 3, 171-180.

[21] Ghernaout, D. and Elboughdiri, N. (2019) Mechanistic Insight into Disinfection Using Ferrate (VI). Open Access Library Journal, 6, e5946.

[22] Ghernaout, D. and Ghernaout, B. (2010) From Chemical Disinfection to Electrodisinfection: The Obligatory Itinerary? Desalination and Water Treatment, 16, 156-175. https://doi.org/10.5004/dwt.2010.1085

[23] Ghernaout, D., Alghamdi, A. and Ghernaout, B. (2019) Microorganisms' Killing: Chemical Disinfection vs. Electrodisinfection. Applied Engineering, 3, 13-19.

[24] Dunlop, P.S.M., McMurray, T.A., Hamilton, J.W.J. and Anthony Byrne, J. (2008) Photocatalytic Inactivation of Clostridium perfringens Spores on $\mathrm{TiO}_{2}$ Electrodes. Journal of Photochemistry and Photobiology A, 196, 113-119. https://doi.org/10.1016/j.jphotochem.2007.11.024

[25] Ghernaout, D. (2017) Microorganisms' Electrochemical Disinfection Phenomena. EC Microbiology, 9, 160-169.

[26] Cañizares, P., Jiménez, C., Martínez, F., Rodrigo, M.A. and Sáez, C. (2009) The pH as a Key Parameter in the Choice between Coagulation and Electrocoagulation for the Treatment of Wastewaters. Journal of Hazardous Materials, 163, 158-164. https://doi.org/10.1016/j.jhazmat.2008.06.073

[27] Ghernaout, D., Naceur, M.W. and Aouabed, A. (2011) On the Dependence of Chlo- 
rine By-Products Generated Species Formation of the Electrode Material and Applied Charge during Electrochemical Water Treatment. Desalination, 270, 9-22. https://doi.org/10.1016/j.desal.2011.01.010

[28] Ghernaout, D., Moulay, S., Ait Messaoudene, N., Aichouni, M., Naceur, M.W. and Boucherit, A. (2014) Coagulation and Chlorination of NOM and Algae in Water Treatment: A Review. International Journal of Environmental Monitoring and Analysis, 2, 23-34. https://doi.org/10.11648/j.ijema.s.2014020601.14

[29] Ghernaout, D. (2017) Water Treatment Chlorination: An Updated Mechanistic Insight Review. Chemistry Research Journal, 2, 125-138.

[30] Ghernaout, D., Alghamdi, A., Aichouni, M. and Touahmia, M. (2018) The Lethal Water Tri-Therapy: Chlorine, Alum, and Polyelectrolyte. World Journal of Applied Chemistry, 3, 65-71. https://doi.org/10.11648/j.wjac.20180302.14

[31] Boucherit, A., Moulay, S., Ghernaout, D., Al-Ghonamy, A.I., Ghernaout, B., Naceur, M.W., Ait Messaoudene, N., Aichouni, M., Mahjoubi, A.A. and Elboughdiri, N.A. (2015) New Trends in Disinfection By-Products Formation upon Water Treatment. Journal of Research \& Developments in Chemistry, 2015, Article ID: 628833. https://doi.org/10.5171/2015.628833

[32] Ghernaout, D. (2013) Advanced Oxidation Phenomena in Electrocoagulation Process: A Myth or a Reality? Desalination and Water Treatment, 51, 7536-7554. https://doi.org/10.1080/19443994.2013.792520

[33] Ghernaout, D. (2019) Virus Removal by Electrocoagulation and Electrooxidation: New Findings and Future Trends. Journal of Environmental Science and Allied Research, 85-90.

[34] Ghernaout, D. (2019) Electrocoagulation and Electrooxidation for Disinfecting Water: New Breakthroughs and Implied Mechanisms. Applied Engineering, 3, 125-133.

[35] Choi, J., Dorji, P., Shon, H.K. and Hong, S. (2019) Applications of Capacitive Deionization: Desalination, Softening, Selective Removal, and Energy Efficiency. Desalination, 449, 118-130. https://doi.org/10.1016/j.desal.2018.10.013

[36] Dai, C., Zhou, Y., Peng, H., Huang, S., Qin, P., Zhang, J., Yang, Y., Luo, L. and Zhang, X. (2018) Current Progress in Remediation of Chlorinated Volatile Organic Compounds: A Review. Journal of Industrial and Engineering Chemistry, 62, 106-119. https://doi.org/10.1016/j.jiec.2017.12.049

[37] Chen, Y., Lin, C., Zhou, Y., Long, L., Li, L., Tang, M., Liu, Z., Pozdnyakov, I.P. and Huang, L.-Z. (2019) Transformation of Roxarsone during UV Disinfection in the Presence of Ferric Ions. Chemosphere, 233, 431-439. https://doi.org/10.1016/j.chemosphere.2019.05.288

[38] Ghernaout, D. (2019) Aeration Process for Removing Radon from Drinking Water: A Review. Applied Engineering, 3, 32-45.

[39] Ghernaout, D., Laribi, C., Alghamdi, A., Ghernaout, B., Ait Messaoudene, N. and Aichouni, M. (2018) Decolorization of BF Cibacete Blue (CB) and Red Solophenyle 3BL (RS) Using Aluminum Sulfate and Ferric Chloride. World Journal of Applied Chemistry, 3, 32-40. https://doi.org/10.11648/j.wjac.20180302.11

[40] Dewil, R., Mantzavinos, D., Poulios, I. and Rodrigo, M.A. (2017) New Perspectives for Advanced Oxidation Processes. Journal of Environmental Management, 195, 93-99. https://doi.org/10.1016/j.jenvman.2017.04.010

[41] Ghernaout, D., Benblidia, C. and Khemici, F. (2015) Microalgae Removal from Ghrib Dam (Ain Defla, Algeria) Water by Electroflotation Using Stainless Steel Electrodes. Desalination and Water Treatment, 54, 3328-3337.

https://doi.org/10.1080/19443994.2014.907749 
[42] Ghernaout, D. (2017) The Holy Koran Revelation: Iron Is a "Sent Down" Metal. American Journal of Environmental Protection, 6, 101-104. https://doi.org/10.11648/j.ajep.20170604.14

[43] Ghernaout, D. and Elboughdiri, N. (2019) Electrocoagulation Process Intensification for Disinfecting Water: A Review. Applied Engineering, 3, 140-147.

[44] Ghernaout, D. and Elboughdiri, N. (2019) Iron Electrocoagulation Process for Disinfecting Water: A Review. Applied Engineering, 3, 154-158.

[45] Ghernaout, D. (2019) Disinfection via Electrocoagulation Process: Implied Mechanisms and Future Tendencies. EC Microbiology, 15, 79-90.

[46] Ghernaout, D. and Ghernaout, B. (2012) Sweep Flocculation as a Second Form of Charge Neutralisation: A Review. Desalination and Water Treatment, 44, 15-28. https://doi.org/10.1080/19443994.2012.691699

[47] Ding, J., Wei, L., Huang, H., Zhao, Q., Hou, W., Kabutey, F.T., Yuan, Y. and Dionysiou, D.D. (2018) Tertiary Treatment of Landfill Leachate by an Integrated Electro-Oxidation/Electro-Coagulation/Electro-Reduction Process: Performance and Mechanism. Journal of Hazardous Materials, 351, 90-97. https://doi.org/10.1016/j.jhazmat.2018.02.038

[48] Fakour, H. and Lo, S.-L. (2018) Formation of Trihalomethanes as Disinfection Byproducts in Herbal Spa Pools. Scientific Reports, 8, 5709-5709. https://doi.org/10.1038/s41598-018-23975-2

[49] Ghernaout, D., Irki, S. and Boucherit, A. (2014) Removal of $\mathrm{Cu}^{2+}$ and $\mathrm{Cd}^{2+}$, and Humic Acid and Phenol by Electrocoagulation Using Iron Electrodes. Desalination and Water Treatment, 52, 3256-3270. https://doi.org/10.1080/19443994.2013.852484

[50] Ghernaout, D., Al-Ghonamy, A.I., Naceur, M.W., Ait Messaoudene, N. and Aichouni, M. (2014) Influence of Operating Parameters on Electrocoagulation of C.I. Disperse Yellow 3. Journal of Electrochemical Science and Engineering, 4, 271-283. https://doi.org/10.5599/jese.2014.0065

[51] Ghernaout, D., Al-Ghonamy, A.I., Irki, S., Grini, A., Naceur, M.W., Ait Messaoudene, N. and Aichouni, M. (2014) Decolourization of Bromophenol Blue by Electrocoagulation Process. Trends in Chemical Engineering, 15, 29-39.

[52] Feng, L., van Hullebusch, E.D., Rodrigo, M.A., Esposito, G. and Oturan, M.A. (2013) Removal of Residual Anti-Inflammatory and Analgesic Pharmaceuticals from Aqueous Systems by Electrochemical Advanced Oxidation Processes: A Review. Chemical Engineering Journal, 228, 944-964. https://doi.org/10.1016/j.cej.2013.05.061

[53] Ghernaout, D., Al-Ghonamy, A.I., Ait Messaoudene, N., Aichouni, M., Naceur, M.W., Benchelighem, F.Z. and Boucherit, A. (2015) Electrocoagulation of Direct Brown 2 (DB) and BF Cibacete Blue (CB) Using Aluminum Electrodes. Separation Science and Technology, 50, 1413-1420. https://doi.org/10.1080/01496395.2014.982763

[54] Irki, S., Ghernaout, D. and Naceur, M.W. (2017) Decolourization of Methyl Orange (MO) by Electrocoagulation (EC) Using Iron Electrodes under a Magnetic Field (MF). Desalination and Water Treatment, 79, 368-377. https://doi.org/10.5004/dwt.2017.20797

[55] Ghernaout, D. (2018) Electrocoagulation Process: Achievements and Green Perspectives. Colloid and Surface Science, 3, 1-5. https://doi.org/10.11648/j.css.20180301.11

[56] Irki, S., Ghernaout, D., Naceur, M.W., Alghamdi, A. and Aichouni, M. (2018) Decolorization of Methyl Orange (MO) by Electrocoagulation (EC) Using Iron Elec- 
trodes under a Magnetic Field (MF). II. Effect of Connection Mode. World Journal of Applied Chemistry, 3, 56-64. https://doi.org/10.11648/j.wjac.20180302.13

[57] Irki, S., Ghernaout, D., Naceur, M.W., Alghamdi, A. and Aichouni, M. (2018) Decolorizing Methyl Orange by Fe-Electrocoagulation Process: A Mechanistic Insight. International Journal of Environmental Chemistry, 2, 18-28. https://doi.org/10.11648/j.ijec.20180201.14

[58] Ghernaout, D. (2019) Greening Electrocoagulation Process for Disinfecting Water. Applied Engineering, 3, 27-31.

[59] Ganiyu, S.O., Vieira dos Santos, E., Tossi de Araújo Costa, E.C. and Martínez-Huitle, C.A. (2018) Electrochemical Advanced Oxidation Processes (EAOPs) as Alternative Treatment Techniques for Carwash Wastewater Reclamation. Chemosphere, 211, 998-1006. https://doi.org/10.1016/j.chemosphere.2018.08.044

[60] Ganzenko, O., Huguenot, D., van Hullebusch, E.D., Esposito, G. and Oturan, M.A. (2014) Electrochemical Advanced Oxidation and Biological Processes for Wastewater Treatment: A Review of the Combined Approaches. Environmental Science and Pollution Research, 21, 8493-8524. https://doi.org/10.1007/s11356-014-2770-6

[61] Ghernaout, D., Touahmia, M. and Aichouni, M. (2019) Disinfecting Water: Electrocoagulation as an Efficient Process. Applied Engineering, 3, 1-12.

[62] Ghernaout, D., Aichouni, M. and Touahmia, M. (2019) Mechanistic Insight into Disinfection by Electrocoagulation: A Review. Desalination and Water Treatment, 141, 68-81. https://doi.org/10.5004/dwt.2019.23457

[63] Ghernaout, D., Alghamdi, A. and Ghernaout, B. (2019) Electrocoagulation Process: A Mechanistic Review at the Dawn of Its Modeling. Journal of Environmental Science and Allied Research, 2, 51-67. https://doi.org/10.29199/2637-7063/ESAR-201019

[64] Ghernaout, D. (2019) Reviviscence of Biological Wastewater Treatment: A Review. Applied Engineering, 3, 46-55.

[65] Ghernaout, D. (2013) The Best Available Technology of Water/Wastewater Treatment and Seawater Desalination: Simulation of the Open Sky Seawater Distillation. Green and Sustainable Chemistry, 3, 68-88. https://doi.org/10.4236/gsc.2013.32012

[66] Ghernaout, D., Alshammari, Y. and Alghamdi, A. (2018) Improving Energetically Operational Procedures in Wastewater Treatment Plants. International Journal of Advances in Applied Sciences, 5, 64-72. https://doi.org/10.21833/ijaas.2018.09.010

[67] Al Arni, S., Amous, J. and Ghernaout, D. (2019) On the Perspective of Applying of a New Method for Wastewater Treatment Technology: Modification of the Third Traditional Stage with Two Units, One by Cultivating Microalgae and Another by Solar Vaporization. International Journal of Environmental Sciences \& Natural Resources, 16, Article ID: 555934. https://doi.org/10.19080/IJESNR.2019.16.555934

[68] Ghernaout, D. (2018) Disinfection and DBPs Removal in Drinking Water Treatment: A Perspective for a Green Technology. International Journal of Advances in Applied Sciences, 5, 108-117. https://doi.org/10.21833/ijaas.2018.02.018

[69] Garcia-Segura, S., Eiband, M.M.S.G., de Melo, J.V. and Martínez-Huitle, C.A. (2017) Electrocoagulation and Advanced Electrocoagulation Processes: A General Review about the Fundamentals, Emerging Applications and Its Association with Other Technologies. Journal of Electroanalytical Chemistry, 801, 267-299. https://doi.org/10.1016/j.jelechem.2017.07.047

[70] Gomes, H.I., Dias-Ferreira, C. and Ribeiro, A.B. (2012) Electrokinetic Remediation of Organochlorines in Soil: Enhancement Techniques and Integration with Other Remediation Technologies. Chemosphere, 87, 1077-1090.

https://doi.org/10.1016/j.chemosphere.2012.02.037 
[71] Hankin, A., Bedoya-Lora, F.E., Ong, C.K., Alexander, J.C., Petter, F. and Kelsall, G.H. (2017) From Millimetres to Metres: The Critical Role of Current Density Distributions in Photo-Electrochemical Reactor Design. Energy \& Environmental Science, 10, 346-360. https://doi.org/10.1039/C6EE03036J

[72] Isidro, J., Brackemeyer, D., Sáez, C., Llanos, J., Lobato, J., Cañizares, P., Matthee, T. and Rodrigo, M.A. (2019) Operating the $\mathrm{CabECO}^{\circledR}$ Membrane Electrolytic Technology in Continuous Mode for the Direct Disinfection of Highly Fecal-Polluted Water. Separation and Purification Technology, 208, 110-115. https://doi.org/10.1016/j.seppur.2018.04.070

[73] Jeon, T.H., Koo, M.S., Kim, H. and Choi, W. (2018) Dual-Functional Photocatalytic and Photoelectrocatalytic Systems for Energy- and Resource-Recovering Water Treatment. ACS Catalysis, 8, 11542-11563. https://doi.org/10.1021/acscatal.8b03521

[74] Lee, S.Y. and Gagnon, G.A. (2014) Review of the Factors Relevant to the Design and Operation of an Electrocoagulation System for Wastewater Treatment. Environmental Reviews, 22, 421-429. https://doi.org/10.1139/er-2014-0009

[75] Lofrano, G., Libralato, G., Minetto, D., De Gisi, S., Todaro, F., Conte, B., Calabrò, D., Quatraro, L. and Notarnicola, M. (2017) In Situ Remediation of Contaminated Marine Sediment: An Overview. Environmental Science and Pollution Research, 24, 5189-5206. https://doi.org/10.1007/s11356-016-8281-x

[76] Lopez-Vizcaino, R., Risco, C., Isidro, J., Rodrigo, S., Saez, C., Canizares, P., Navarro, V. and Rodrigo, M.A. (2017) Scale-Up of the Electrokinetic Fence Technology for the Removal of Pesticides. Part I: Some Notes about the Transport of Inorganic Species. Chemosphere, 166, 540-548.

https://doi.org/10.1016/j.chemosphere.2016.09.113

[77] Lopez-Vizcaino, R., Risco, C., Isidro, J., Rodrigo, S., Saez, C., Canizares, P., Navarro, V. and Rodrigo, M.A. (2017) Scale-Up of the Electrokinetic Fence Technology for the Removal of Pesticides. Part II: Does Size Matter for Removal of Herbicides? Chemosphere, 166, 549-555. https://doi.org/10.1016/j.chemosphere.2016.09.114

[78] Lu, L., Yazdi, H., Jin, S., Zuo, Y., Fallgren, P.H. and Ren, Z.J. (2014) Enhanced Bioremediation of Hydrocarbon-Contaminated Soil Using Pilot-Scale Bioelectrochemical Systems. Journal of Hazardous Materials, 274, 8-15.

https://doi.org/10.1016/j.jhazmat.2014.03.060

[79] Luo, T., Abdu, S. and Wessling, M. (2018) Selectivity of Ion Exchange Membranes: A Review. Journal of Membrane Science, 555, 429-454.

https://doi.org/10.1016/j.memsci.2018.03.051

[80] Marselli, B., Garcia-Gomez, J., Michaud, P.A., Rodrigo, M.A. and Comninellis, C. (2003) Electrogeneration of Hydroxyl Radicals on Boron-Doped Diamond Electrodes. Journal of the Electrochemical Society, 150, D79-D83.

https://doi.org/10.1149/1.1553790

[81] Martínez-Huitle, C.A., Rodrigo, M.A., Sirés, I. and Scialdone, O. (2015) Single and Coupled Electrochemical Processes and Reactors for the Abatement of Organic Water Pollutants: A Critical Review. Chemical Reviews, 115, 13362-13407. https://doi.org/10.1021/acs.chemrev.5b00361

[82] Millán, M., Rodrigo, M.A., Fernández-Marchante, C.M., Díaz-Abad, S., Peláez, M.C., Cañizares, P. and Lobato, J. (2018) Towards the Sustainable Powering of the Electrocoagulation of Wastewater through the Use of a Solar-Vanadium Redox Flow Battery: A First Approach. Electrochimica Acta, 270, 14-21. https://doi.org/10.1016/j.electacta.2018.03.055

[83] Mook, W.T., Aroua, M.K. and Issabayeva, G. (2014) Prospective Applications of 
Renewable Energy Based Electrochemical Systems in Wastewater Treatment: A Review. Renewable \& Sustainable Energy Reviews, 38, 36-46. https://doi.org/10.1016/j.rser.2014.05.042

[84] Ahmed, M.B., Zhou, J.L., Ngo, H.H., Guo, W., Thomaidis, N.S. and Xu, J. (2017) Progress in the Biological and Chemical Treatment Technologies for Emerging Contaminant Removal from Wastewater: A Critical Review. Journal of Hazardous Materials, 323, 274-298. https://doi.org/10.1016/j.jhazmat.2016.04.045

[85] Ghernaout, D. (2017) Environmental Principles in the Holy Koran and the Sayings of the Prophet Muhammad. American Journal of Environmental Protection, 6, 75-79. https://doi.org/10.11648/j.ajep.20170603.13

[86] Olvera-Vargas, H., Zheng, X., Garcia-Rodriguez, O. and Lefebvre, O. (2019) Sequential "Electrochemical Peroxidation Electro-Fenton" Process for Anaerobic Sludge Treatment. Water Research, 154, 277-286. https://doi.org/10.1016/j.watres.2019.01.063

[87] Ghernaout, D. (2019) Electrocoagulation Process for Microalgal Biotechnology: A Review. Applied Engineering, 3, 85-94.

[88] Ghernaout, D. (2014) The Hydrophilic/Hydrophobic Ratio vs. Dissolved Organics Removal by Coagulation: A Review. Journal of King Saud University-Science, 26, 169-180. https://doi.org/10.1016/j.jksus.2013.09.005

[89] Ghernaout, D., Al-Ghonamy, A.I., Boucherit, A., Ghernaout, B., Naceur, M.W., Ait Messaoudene, N., Aichouni, M., Mahjoubi, A.A. and Elboughdiri, N.A. (2015) Brownian Motion and Coagulation Process. American Journal of Environmental Protection, 4, 1-15. https://doi.org/10.11648/j.ajeps.s.2015040501.11

[90] Ghernaout, D., Al-Ghonamy, A.I., Naceur, M.W., Boucherit, A., Messaoudene, N.A., Aichouni, M., Mahjoubi, A.A. and Elboughdiri, N.A. (2015) Controlling Coagulation Process: From Zeta Potential to Streaming Potential. American Journal of Environmental Protection, 4, 16-27. https://doi.org/10.11648/j.ajeps.s.2015040501.12

[91] Ghernaout, D. and Boucherit, A. (2015) Review of Coagulation's Rapid Mixing for NOM Removal. Journal of Research \& Developments in Chemistry, 2015, Article ID: 926518. https://doi.org/10.5171/2015.926518

[92] Ghernaout, D. (2017) Entropy in the Brownian Motion (BM) and Coagulation Background. Colloid and Surface Science, 2, 143-161.

[93] Ghernaout, D., Simoussa, A., Alghamdi, A., Ghernaout, B., Elboughdiri, N., Mahjoubi, A., Aichouni, M. and El-Wakil, A.E.A. (2018) Combining Lime Softening with Alum Coagulation for Hard Ghrib Dam Water Conventional Treatment. International Journal of Advanced and Applied Sciences, 5, 61-70. https://doi.org/10.21833/ijaas.2018.05.008

[94] Djezzar, S., Ghernaout, D., Cherifi, H., Alghamdi, A., Ghernaout, B. and Aichouni, M. (2018) Conventional, Enhanced, and Alkaline Coagulation for Hard Ghrib Dam (Algeria) Water. World Journal of Applied Chemistry, 3, 41-55. https://doi.org/10.11648/j.wjac.20180302.12

[95] Kellali, Y. and Ghernaout, D. (2019) Physicochemical and Algal Study of Three Dams (Algeria) and Removal of Microalgae by Enhanced Coagulation. Applied Engineering, 3, 56-64.

[96] Ghernaout, B., Ghernaout, D. and Saiba, A. (2010) Algae and Cyanotoxins Removal by Coagulation/Flocculation: A Review. Desalination and Water Treatment, 20, 133-143. https://doi.org/10.5004/dwt.2010.1202

[97] Ghernaout, D. and Ghernaout, B. (2012) On the Concept of the Future Drinking Water Treatment Plant: Algae Harvesting from the Algal Biomass for Biodiesel Produc- 
tion-A Review. Desalination and Water Treatment, 49, 1-18. https://doi.org/10.1080/19443994.2012.708191

[98] Ghernaout, D., Badis, A., Braikia, G., Matâam, N., Fekhar, M., Ghernaout, B. and Boucherit, A. (2017) Enhanced Coagulation for Algae Removal in a Typical Algeria Water Treatment Plant. Environmental Engineering and Management Journal, 16, 2303-2315. https://doi.org/10.30638/eemj.2017.238

[99] Ghernaout, D. (2018) Magnetic Field Generation in the Water Treatment Perspectives: An Overview. International Journal of Advances in Applied Sciences, 5, 193-203. https://doi.org/10.21833/ijaas.2018.01.025

[100] Ghernaout, D., Aichouni, M. and Alghamdi, A. (2018) Applying Big Data (BD) in Water Treatment Industry: A New Era of Advance. International Journal of Advances in Applied Sciences, 5, 89-97. https://doi.org/10.21833/ijaas.2018.03.013

[101] Alshammari, Y., Ghernaout, D., Aichouni, M. and Touahmia, M. (2018) Improving Operational Procedures in Riyadh's (Saudi Arabia) Water Treatment Plants Using Quality Tools. Applied Engineering, 2, 60-71.

[102] Ghernaout, D. (2019) Greening Cold Fusion as an Energy Source for Water Treatment Distillation: A Perspective. American Journal of Quantum Chemistry and Molecular Spectroscopy, 3, 1-5.

[103] Xiao, R., Liu, K., Bai, L., Minakata, D., Seo, Y., Göktaş, R.K., Dionysiou, D.D., Tang, C.-J., Wei, Z. and Spinneyh, R. (2019) Inactivation of Pathogenic Microorganisms by Sulfate Radical: Present and Future. Chemical Engineering Journal, 371, 222-232. https://doi.org/10.1016/j.cej.2019.03.296

[104] Malato, S., Fernández-Ibáñez, P., Maldonado, M.I. and Oller, I. (2013) Solar Photocatalytic Processes: Water Decontamination and Disinfection (Ch. 15). In: Suib, S.L., Ed., New and Future Developments in Catalysis, Solar Photocatalysis, Elsevier B.V., Amsterdam, 371-393. https://doi.org/10.1016/B978-0-444-53872-7.00017-0

[105] Alvarez-Guerra, E., Dominguez-Ramos, A. and Irabien, A. (2011) Design of the Photovoltaic Solar Electro-Oxidation (PSEO) Process for Wastewater Treatment. Chemical Engineering Research and Design, 89, 2679-2685.

https://doi.org/10.1016/j.cherd.2011.05.003

[106] Ghernaout, D., Alghamdi, A., Touahmia, M., Aichouni, M. and Ait Messaoudene, N. (2018) Nanotechnology Phenomena in the Light of the Solar Energy. Journal of Energy, Environmental \& Chemical Engineering, 3, 1-8. https://doi.org/10.11648/j.jeece.20180301.11

[107] Ghernaout, D. (2017) Water Reuse (WR): The Ultimate and Vital Solution for Water Supply Issues. International Journal of Sustainable Development Research, 3, 36-46. https://doi.org/10.11648/j.ijsdr.20170304.12

[108] Ghernaout, D. (2018) Increasing Trends towards Drinking Water Reclamation from Treated Wastewater. World Journal of Applied Chemistry, 3, 1-9. https://doi.org/10.11648/j.wjac.20180301.11

[109] Ghernaout, D., Alshammari, Y., Alghamdi, A., Aichouni, M., Touahmia, M. and Ait Messaoudene, N. (2018) Water Reuse: Extenuating Membrane Fouling in Membrane Processes. International Journal of Environmental Chemistry, 2, 1-12. https://doi.org/10.11648/j.ajche.20180602.12

[110] Ghernaout, D., Elboughdiri, N. and Al Arni, S. (2019) Water Reuse (WR): Dares, Restrictions, and Trends. Applied Engineering, 3, 159-170.

[111] Ghernaout, D., Elboughdiri, N. and Ghareba, S. (2019) Drinking Water Reuse: One-Step Closer to Overpassing the "Yuck Factor". Open Access Library Journal, 6, e5895. https://doi.org/10.4236/oalib.1105895 
[112] Lefebvre, O. (2018) Beyond NEWater: An Insight into Singapore's Water Reuse Prospects. Current Opinion in Environmental Science \& Health, 2, 26-31. https://doi.org/10.1016/j.coesh.2017.12.001

[113] Maryam, B. and Büyükgüngör, H. (2019) Wastewater Reclamation and Reuse Trends in Turkey: Opportunities and Challenges. Journal of Water Process Engineering, 30, Article ID: 100501. https://doi.org/10.1016/j.jwpe.2017.10.001

[114] Lyu, S., Chen, W., Zhang, W., Fan, Y. and Jiao, W. (2016) Wastewater Reclamation and Reuse in China: Opportunities and Challenges. Journal of Environmental Sciences, 39, 86-96. https://doi.org/10.1016/j.jes.2015.11.012

[115] Ghernaout, D. and Ghernaout, B. (2011) On the Controversial Effect of Sodium Sulphate as Supporting Electrolyte on Electrocoagulation Process: A Review. Desalination and Water Treatment, 27, 243-254. https://doi.org/10.5004/dwt.2011.1983

[116] Ghernaout, D. and El-Wakil, A. (2017) Requiring Reverse Osmosis Membranes Modifications: An Overview. American Journal of Chemical Engineering, 5, 81-88. https://doi.org/10.11648/j.ajche.20170504.15

[117] Ghernaout, D. (2017) Reverse Osmosis Process Membranes Modeling: A Historical Overview. Journal of Civil, Construction and Environmental Engineering, 2, 112-122.

[118] Ghernaout, D., El-Wakil, A., Alghamdi, A., Elboughdiri, N. and Mahjoubi, A. (2018) Membrane Post-Synthesis Modifications and How It Came about. International Journal of Advanced and Applied Sciences, 5, 60-64. https://doi.org/10.21833/ijaas.2018.02.010

[119] Ait Messaoudene, N., Naceur, M.W., Ghernaout, D., Alghamdi, A. and Aichouni, M. (2018) On the Validation Perspectives of the Proposed Novel Dimensionless Fouling Index. International Journal of Advances in Applied Sciences, 5, 116-122. https://doi.org/10.21833/ijaas.2018.07.014

[120] Ghernaout, D. (2019) Brine Recycling: Towards Membrane Processes as the Best Available Technology. Applied Engineering, 3, 71-84. 